\title{
A perspective of counter-hegemonic analysis and territorial transformation
}

\author{
Marcos Aurelio Saquet \\ State University of West Paraná (UNIOESTE), 85605-010, Francisco Beltrão, Brazil \\ Correspondence: Marcos Aurelio Saquet (saquetmarcos@hotmail.com)
}

\begin{abstract}
Received: 16 April 2018 - Revised: 10 November 2018 - Accepted: 12 November 2018 - Published: 20 November 2018
\end{abstract}
\begin{abstract}
This paper shows the results from my research trajectory and my collaboration in cooperative projects with economically disadvantaged people of the urban periphery of Francisco Beltrão (Brazil). I initially reflect on the relevance of an analysis of urban social movements, asking how current urban conflicts can be understood from a territorial perspective. I will first develop a specific definition of territory, which seeks to become operative in collaboration with diverse subjects and in the analysis of territorial development based on the place. Such a conceptualization of territory provides a territorial analysis furthering transformation towards a fairer, solidary, and ecological society. I show how this fairer society emerges in a multidimensional way, emanating from the processes of territorialization, deterritorialization, and reterritorialization. Finally, by linking these processes with the current processes of territorial development (in research, analysis, and active participation), this study contributes to a more dialogical and counter-hegemonic perspective, especially in relation to Latin America.
\end{abstract}

1

\section{Introduction}

Over the last 3 decades, there have been emerging postcolonial approaches related to urban studies in favor of the decentralization of knowledge production (Schwarz and Streule, 2017), in a movement against the Eurocentric coloniality of power (Quijano, 2000, 2007), requiring an intellectual exchange and an epistemic dialogue (Schwarz and Streule, 2017). This change is taking place in scientific research, considering the dialogical, respectful, and participatory practice (dialectical unity between theory and practice) with the subjects, contributing directly to build a fairer and more ecological society.

I know that the production of knowledge is interdisciplinary and simultaneously has a historical and geographical territorial content, a mix of knowledge produced jointly in a transversal way. There is scientific and popular contents with scientific and social praxis (scientific bases, peasant management, social movements, indigenous knowledge, participatory activities, etc.) (Padilla and Guzmán, 2009), as well as technical knowledge and networking among people (Coraggio, 2004). In this conception, technical, academic, and scientific knowledge are worked together with popular knowl- edge, linked to the historically perpetuated tradition, from generation to generation, in the countryside and in the city.

This issue is at the same time theoretical, conceptual, operational, and political; therefore, it requires, from researchers, a lot of methodological clarity and an ideological and political option that is linked to the power of the decolonial movement (Quijano, 2007) and being counter-hegemonic, in favor of dialogue, debate, cooperation, and solidarity, with a centrality in the practice among the different subjects, in teaching, research, and cooperation. Research and participatory action need to be seen as a philosophy of life (Fals Borda, 2008).

This movement has occurred since 1970, when institutions and some alternative research procedures and popular actions were created with initiatives carried out in different countries, having great international impetus from the Congress of Cartagena in 1977, concretizing studies that were more linked to the daily life of subjects and interacting with them (Fals Borda, 2008). The participatory action investigation processes began in 1972, in Colombia (Fals Borda, 1981), due to the verification of the colonial and Eurocentric domination historically realized in Latin America, as I briefly describe in Sect. 2. 
Popular participation is assuming centrality in different countries, comprehended from the concepts of territoriality and temporality, understood as cooperation and solidarity focused on the territorial development of local base. Cooperation and solidarity take place in a synthesis of practice centered on people as historical-social beings, creators, and transformer who, when reflecting on their practice, can philosophize critically and consciously (Vazquez, 1990). There is an indissoluble unity between theory and practice.

For people to change the world they must transform in praxis because there is a transformation of people and the world simultaneously. Action in the real moment is inseparable from a consciousness formation. Praxis must, therefore, be creative, conscious, and reflexive, as Vazquez (1990) states, in an effective movement for the construction of decision-making and dialogic autonomy, in the terms described by Freire (2011a, b).

In this way, I initially problematize Latin American territorial formation, followed by a synthesis on the concept of territory and the approach adopted in our research and cooperation projects, presenting, in the final part of the text, some results that $I$ have already achieved in these projects, from our direct collaboration with the subjects studied in a participatory movement in research and actions at the same time of resistance to capital and counter-hegemony. There are three paragraphs that are separated in order to facilitate reading and comprehension of the text, especially our argument about the problem of colonization in Latin America, the option of a territorial approach, and the empirical demonstration with the analyses.

\section{Neocolonial extractivism and Latin American territory}

Latin America - according to Lizárraga and Vacaflores (2014) and Rodríguez et al. (2014) - was named Abya Yala (which means "land bloomed to life") by the Kuna peoples before the discovery by Europeans; this ends up historically fulfilling, in the international division of labor, a subordinate and complementary role in the production of food and raw materials. Bartra (2014a) reveals the problem of colonization when reflecting on capitalist territorial neoexpansionism and the unsustainability of industrial agriculture, with significant impacts on Latin American cities.

Latin America was involved in the international capitalist territorial appropriation and expansion movement from the late 15th century, serving as colonies of Spanish and Portuguese exploration. It is a violent process of expropriation and exploitation of natural and cultural riches, based on capitalist principles and practices such as concentration of wealth and power centralization.

Historically, there are negative territorial impacts in all Latin American countries, on public health, food quality, ecosystem integrity, knowledge, and land appropriation, for which the intense expansion of transnational corporations investing in food and biofuel production leads to deterritorialization of families and it dissolves relations of reciprocity and solidarity (Martínez Valle, 2015). During the imperialist expansion, from the 19th century, through monopoly and the state's capital, based on the dominant interests of the imperialist and internal bourgeoisie, agricultural production for export and the importation of industrialized products was promoted (Quijano, 1981).

These impacts are verified in the strengthening and hegemony of agribusiness (Llambí, 2012), in agrofuel production (Hidalgo, 2014), and in the recolonization of mining capital (Rodríguez, Lizárraga and Bórquez, 2014) and they are specific for the different countries in Latin America; however, there is a more general movement linked to the transnational expansion of economic neoliberalism. This process generates extreme inequalities, a decline in agricultural diversity, a predominance of large-scale monocultures, the introduction of genetically modified organisms, the use of chemical inputs, rural expropriation, loss of autonomy, etc. (Harguindeguy, 2014).

They are all elements and processes that seriously threaten economically disadvantaged people specifically and everyone's existence (Bartra, 2014b) and that are inherent to colonialism and coloniality as mechanisms of classification of race and domination in Eurocentric capitalism, benefiting a minority and mediating the extraction of wealth (Quijano, 2000, 2007; Teubal, 2011). Through the classification of race, there is an intense process of social domination between conquerors and the conquered. The indigenous peoples are considered inferior and, therefore, in oppressive logic, they must be civilized and educated with European intellectual views (Quijano, 2007), which prevailed as an urban and rural civilizational movement, producing merchants who sold products that were different from what the indigenous peoples used daily.

In an attempt to summarize, it is very plausible to affirm that there is an expansion of commodities with a predominance of financial capital, specialization, orientation to foreign market, expropriation of the economically disadvantaged (and indigenous peoples), and large operating units (Teubal, 2011). There is territory control and exploitation by a multiplicity of national and international actors related to extractive industries and to neoliberal expansion, generating conflicts and deep inequalities among the state, companies, and indigenous communities (Garavito, 2012), as well as direct impacts on the cities, mainly in estate speculation (rents) and growth of the peripheries with low-income workers.

In order to illustrate this process, I have selected some recent data from the Economic Commission for Latin America and the Caribbean (ECLAC, 2013-2015), as they reveal the high rates of urban and rural poverty in countries such as Ecuador, Mexico, Bolivia, and Brazil; infant mortality rates may also be considered high, although substantial progress has been made in medicine; there is a large predominance of 
salaried and self-employed workers with low wages, inherent to capitalist production-circulation-consumption.

The large-scale agricultural production process based on chemical inputs and agricultural machinery contributes to keeping Latin America in a position of technological and financial dependence in the international market. Thus, it is not difficult to deduce the predominance of social relations that are subordinate and have a strong environmental impact, perpetuating domination and poverty in rural and urban areas, as well as national states strongly linked to regionally hegemonic social groups and to the international bourgeoisie.

In the cities, especially in metropolitan areas (Mexico City, Bogotá, Lima, São Paulo, Rio de Janeiro, Buenos Aires, La Paz, etc.), there is a marked concentration of wealth, a violent process of slum-dwelling, occupation of valley bottom areas and hillsides that should be preserved, violence, unemployment, important commercial and financial centers interconnected in transnational networks, and social and territorial exclusion, among other characteristics that also reveal the historical process of the formation of Latin America centered on interests of the national and international bourgeoisie very well. It is precisely on the urban scale, especially in the poor neighborhoods, that popular movements have emerged defying the dominant system, as Zibechi (2015) consistently affirms and I show in Sect. 4.

This problem obviously requires representation, explanation, and social transformation, a specific approach, and action for its understanding, as I try to elaborate below.

\section{A counter-hegemonic territorial approach}

In order to understand and explain this problematic of subordinating and alienating, devastating and polluting colonial and imperial development, I adopt as theoretical orientation the territorial analysis paradigm of development (Bagnasco, 1978; Saquet, 2003, 2007, 2012, 2015, 2017) acting in projects, programs, and processes of local development from the paradigm of active territoriality (Dematteis, 2001; Saquet, 2007, 2009, 2015), understanding the identity linked to the projection and the self-government of the future (Magnaghi, 2000, 2006).

I also ratify the premises of the reticular paradigm in the terms indicated by Camagni (1993), along with the TDR process - territorialization-deterritorializationreterritorialization - (Raffestin, 1984; Saquet, 2003, 2015, 2017; Magnaghi, 2000, 2006). Territory, therefore, is the result of society-nature relations and the historical appropriation of space, and it can assume the meaning of place, mobilization, struggle, and political and cultural resistance. There is a process of territorial appropriation and transformation made effective through power relations, circulation and communication networks, and cultural identities, characterizing different territories and constantly changing, and it can be reorganized with people to live better, as we will describe in this text.

Another condition for social transformation is consciousness of incompleteness and humility (Freire, 2011b). When we are aware of the incompleteness, we can deepen the debates, researches, classes, and exchanges; renew techniques, and conceptions; and go beyond the work I have performed, taking advantage of and valuing what has already been carried out by others, based on our theoretical and methodological choices and policies made with autonomy and versatility.

These TDR, territorial, active territoriality, and network paradigms may contribute, paraphrasing Sánchez (2014), Harguindeguy (2014), and Hidalgo and Fernández (2012), to constructing a counter-hegemonic perspective: this may occur from the much-needed dialogue among subjects of different ethnicities, religions, areas, times, etc., bringing together knowledge, expertise, practices, and theories in a practice of social and territorial transformation identifying, knowing, and valuing agroecological practices and the craftsmanship in the countryside and in the city. This paradigm must be contrary to the Eurocentric and colonial capitalism (Quijano, 2000), autonomous, participatory, dialogical, reflexive, and propositional to try to break with dependence, subordination, exploitation, domination, and degradation. There is an urgent need to build, together with universal knowledge, contextualized knowledge with our singularities and complexities, making it available to urban and rural communities for our collective strengthening (Fals Borda and Mora-Osejo, 2004; Saquet, 2017).

This is a way to build popular knowledge, less academic and dichotomizing, from the subject/researchersubject/researched relation (different from the subject-object relation), facilitating the understanding of historical reality and contributing directly to the concretization of a more just territorial transformation, carried out with the participation of the inhabitants of each territory, enhancing and boosting their cultural knowledge.

Therefore, it requires, from researchers, an ideological and political option, humility, and solidarity, producing knowledge that is directly useful to the people, with the participation (of the researcher and researched) continued throughout all phases of research and territorial transformation actions.

While dominant knowledge corresponds to the specialized and rational Western science, linked to capitalist social domination and serving the interests of the dominant class, also called hegemonic knowledge (Fals Borda, 1981; Mignolo, 2003), emerging knowledge, as we defend and we choose, corresponds to practical knowledge, to the daily popular knowledge used to work and to live, attending to the urgencies and needs of the people, characterizing itself as a popular science (Fals Borda and Mora-Osejo, 2013).

In the construction of the knowledge of this possible counter-hegemonic paradigm, the territorial anchorage (Pecqueur and Zimmermann, 2002; Magnaghi, 2015) or arraigo (Harguindeguy, 2014), together with the relations of belong- 
ing, proximity, reciprocity, and trust, is also fundamental since arraigo can mean a significant insertion in the community (Rullani, 1997). This insertion means social integration working with the subjects, the countryside, and the city, contributing to the potential of their knowledge and cultural values, as I elaborate in Sect. 4.

We need, therefore, to build endogenous paradigms rooted in our own circumstances that reveal the complex reality that we have and live (Fals Borda and Mora-Osejo, 2013:223).

In my approach and cooperation conception I understand that subjects are multiple, in urban and rural spaces, living daily as syntheses of society-nature relations. The territory contains these relations and it means, at a first level, a space of (in)formation, mobilization, struggle, and resistance against the capital agents, in addition to being the object of study and conceptual orientation in scientific analysis (Saquet, 2014, 2015, 2017). It is a concept in which, in practice, I work together with citizens and the economically disadvantaged in the social projects of territorial resistance and counter-hegemony.

In this way, territory has some fundamental epistemological and ontological characteristics: (a) it is appropriated and dominated and it has a political and economic content involving points, networks, and meshes (Indovina and Calabi, 1974) that also take place every day on cultural and environmental levels. (b) It is produced at different scale levels (Magnaghi, 1976; Dematteis, 1985; Raffestin, 1993; Brunet, 2009; Saquet, 2007) with a relational meaning, nominalizing trans-territorial relations (Camagni, 1993, 1997), which means transversality (Dematteis, 1995; Rullani et al., 2000). The networks and meshes are at the base of each territory (Indovina and Calabi, 1974; Magnaghi, 1976; Raffestin, 1987, 1993; Dematteis, 1985, 1995, 2001; Rullani, 1997). (c) It is organized by means of territorialities in a historical process centered on power relations, networks, and cultural identities (Raffestin, 1977, 1986, 2003, 2005; Camagni, 1993; Racine, 2002; Saquet, 2003, 2012, 2016, 2017).

This means that the historical process is also geographic, in a broad movement of deterritorialization and reterritorialization: in deterritorialization, there is a loss of the initially appropriated and constructed territory and the suppression of boundaries, as stated by Raffestin (1984), and in reterritorialization reproduction of the elements of the previous territory occurs, at least in some of its characteristics. This process occurs in the same space or among different spaces, in the same period or among different periods.

In view of the neocolonial and neoliberal processes it is therefore necessary to consider these territorial aspects, contextualized in each space-time relationship, understanding and transforming them into cooperative, solidary, popular, participatory, and ecological work. This movement of political and cultural (in)formation can pass through ethnic consciousness, when collective representations take on an ideo- logical content, relating to identity and difference with others, indicating the existence of a culture of resistance (Bartolomé, 2000).

Resistance means struggle in favor of the subjects' culture and identity, no matter if they are indigenous, Afrodescendants, Brazilians, Bolivians, economically disadvantaged, Italians etc., a process I learned from our families and friends, neighbors, and other distant subjects, establishing social bonds. I believe that participation implies a relationship among the subjects, who are aware and who share goals and actions, considering trust relationships established in each research and cooperation process. This means mutual respect, understanding, communication, and identity (Fals Borda, 1987). The participation must, therefore, take place in the social and social-territorial interaction movement, in the interpretation of reality with the goal of its transformation, which is also participatory.

It is necessary to consider the construction of useful knowledge for just causes, discovering other types of knowledge, of other peoples, interacting and generating more complete and applicable knowledge for reality (Fals Borda, 2008). Research and cooperation (territorial transformation) must be built with the population, their knowledge, techniques, and technologies appropriate for each territory.

This is a movement in which subjects feel bound to a social class and a place. (Harvey, 1982; Becattini, 2000, 2009, 2015; Magnaghi, 2000, 2006, 2015; Quaini, 2010; Saquet, 2014,2015 , 2017). I believe, therefore, that class consciousness, however politicized and qualified it may be, is not sufficient in the decolonization and counter-hegemonic movement: there is an urgent need for dynamism, mobilization, participation, and struggle in favor of the subjects of each place and territory, movements articulated in a network. I can obtain the construction of class and place consciousness, territorializing in networks of cooperation, sharing and solidarity based on the needs and desires of the individuals, groups and classes, valuing the local ties and the (im)material conditions of each territory. This occurs in a movement of deep knowledge of the history of the local productive systems, identifying local potential, orienting development processes in different perspectives, and valuing the territories and their inhabitants (Becattini, 2009). Development of places must occur as development in the places; for this reason, the return to the territory is justified (Becattini, 2009, 2015; Magnaghi, 2015).

Place consciousness is vital for social identification and participation and for the reproduction of the place as a place of coexistence with community relations, and it can mean a possible antidote to economic globalization (Becattini and Magnaghi, 2015). The inhabitants need to feel alive, important, recognized, and valued and like they belong to the place, the street, the urban residential condominium, the neighborhood, the rural community, the city, the short networks, the hydrographic region, the state, the river, and finally, the territory. 


\section{Resistance and counter-hegemony in territorial practice}

This perspective of approach and community work is being constructed with other teachers, researchers, and cooperation workers, through a historical, reticular, relational, and pluridimensional conception (Dansero and Zobel, 2007; Saquet, 2015, 2017) or (im)material conception that recognizes and effectively considers society-nature relations (Saquet, 2007). It is a movement in which I try to integrate theory and empirical work, concepts, and practices in order to collaborate in the revision of geography as a science and in the use by the subjects who were studied of knowledge produced in the academic field, preferably, by working with them.

In the research and action project that we will describe next, researchers and the researched participated during the phases of research and territorial transformation, building together popular and counter-hegemonic knowledge: we cooperate with them in a practice of solidarity centered on the subject-subject relation.

Since 1996, I have carried out research and cooperation projects, always working with urban and rural dwellers, workers and agroecological and artisan food producers, directly contributing to the activation processes of the subjects, valuing their knowledge and techniques, identities, and political mobilizations, in harmony with the territorial singularities. They are projects in which the practice occurred in the process, through the actions of the different subjects, trying to overcome difficulties and limits, valuing and enhancing territorial anchoring, solidarity, short production, and commercialization networks, together with the self-organization of the subjects in a process of counter-hegemony.

In the Life in the Neighborhood Project (Projeto Vida no Bairro - PVB), 2002-2006, the subjects we (I, as a subject working with the subjects studied, collaborating) worked with were different from those in the rural areas. In this initiative of collaboration among several public institutions, associations (mainly the resident association of São Francisco neighborhood), and unions (of urban and rural workers), we carried out research and cooperation actions with the urban periphery residents, directly contributing to the solution of problems which could improve the living conditions of the inhabitants of the São Francisco neighborhood - city of Francisco Beltrão (Paraná State, Brazil).

The main activities were meetings with the residents of the neighborhood; jointly defining the project coordination team; meetings with the residents of the main streets of the neighborhood in order to consult and involve them in the actions of the project, identifying problems and solutions that were more urgent; defining the cooperation to carry out the planned activities with residents; data collection and analysis with the participation of some inhabitants of the neighborhood; socialization and discussion of the diagnosis made; joint discussion and definition of priority actions (identifying the main problems that would be solved, the goals to be achieved, the actions, where they would happen, how and who was responsible for each planned activity); evaluation and monitoring of the activities carried out; writing of the work plan and the actions discussed with the residents, such as (in)formative courses (good practices of the domestic unit (food and hygiene manipulation), training of political leaders, guitar music, handicraft courses (of domestic use)); restoration of daily lines of public transport, regularization of the land and house property titles; public lighting of some streets; creation of computer labs, etc. (Saquet et al., 2005; Saquet, 2015; Saquet and Flávio, 2015).

We have worked for 5 years carrying out a work with residents of the urban periphery, who had unique characteristics such as predominance of families with two to five members $(82 \%)$, in an age group mainly between 25 and 45 years old $(28 \%)$, with only one member of the family working regularly (masons, maids, seamstresses, house painters, and mechanics) and with an expressive number of children and young people (40\%); most of the adults were migrants from other nearby municipalities, from small towns and rural spaces (farmers). They had small houses (masonry and/or wood construction) and many of the properties were in an irregular situation. The other two very important characteristics that we identified, which guided our actions, were (i) the fact that about $70 \%$ of those interviewees did not participate in any social and political organization; (ii) despite the problems in the São Francisco neighborhood, $93 \%$ of people stated that they liked to live there.

Thus, since the end of 2001, we have been working on construction of the project: one of the first activities was carrying out a seminar to discuss life in cities, articulating politically different public institutions in order to create a basis of solidarity work. In March of 2002, we had already selected the São Francisco neighborhood, after some visits and preliminary conversations with some local leaders, and then beginning the more systematic discussion about the diagnosis of the neighborhood and the formation of the work team. Soon thereafter, when presenting the data collected, tabulated, and analyzed to the residents of the neighborhood, we worked with participant research, that is, with small group conversations, in which people shared with all those present their perceptions and aspirations for the future in the neighborhood, aiming to improve the conditions of daily life. This served as a basis for the joint definition of the most urgent priority actions with those responsible for each action discussed and approved at a meeting held in the neighborhood, followed by meetings held in some of the streets to increase popular participation, in the Prefeitura Municipal de Francisco Beltrão, at Escola Estadual São Miguel, at Escola Municipal Madre Boa Ventura, at Universidade Estadual do Oeste do Paraná (UNIOESTE), and at the Sindicato dos Trabalhadores no Comércio de Francisco Beltrão.

This means that one of the main paths we have considered, in order to improve the quality of life of the population, was the popular organization with our direct participa- 
tion (in the research and territorial transformations), working together with mediating institutions and the diversity of subjects. The PVB has been oriented towards the practice of science itself to contribute to overcoming daily oppression through political awareness, organization, and popular transformation. There was therefore a combination of efforts, sharing knowledge and the participation of different subjects in all the activities carried out between 2002 and 2006. "In this sense, more than a project or an individual will, the PVB is a way to see and understand the world, a strategy of joint actions, with a strong participatory character" (Saquet et al., 2005:23).

In the PVB, we have worked with different subjects from guiding principles of practice such as participation, interdisciplinarity, diversification of productive and cultural activities, political formation, and solidarity, involving these subjects in research and actions, achieving very relevant results, inherent to understanding and acting in territorial development - at that time called community involvement - in a pluridimensional perspective: health and environmental sanitation (family, housing, and infrastructure); leisure and culture (recreation, courses, and workshops); education (formal and informal); and dissemination of the projects with the direct involvement of the São Francisco neighborhood residents - Francisco Beltrão city.

Actions - participatory in research and cooperation aimed at development respecting nature, culture, and the immediate needs of the local population, can be strengthened politically through social participation. The PVB was participatory in the study of the neighborhood and participant in the territorial transformation actions.

i. It was also interdisciplinary, involving collaborating subjects of architecture, law (lawyer), geography, administration, economics, food science, popular knowledge of the inhabitants of the São Francisco neighborhood, geography undergraduate students of UNIOESTE, and the employees of the Trade Union of Trade Workers of Francisco Beltrão, who are familiar with everyday life in the neighborhoods of this city.

ii. It was (in)formative and mobilizing, working against the political hegemony of the bourgeois state (with extremely fragile, sectoral, and bureaucratic policies, without the involvement of the population) and against the economic domination of the great industrialists and merchants.

iii. Territorial research and transformation activities were solidary, with mutual respect among the different subjects involved, aiming to improve the conditions of daily life in the territory through participatory analysis and popular transformation.

This means that the way we work with neighborhood residents in a participatory, respectful, and dialogued way, valuing their knowledge, was fundamental in generating a more coherent analysis of neighborhood problems and actions taken from their most urgent needs. Popular knowledge and science were integrated to guide the actions of political mobilization and popular transformation.

Of course, in the process of grassroots research, solidarity, and dialogue, we had difficulties, in both involving as many of the inhabitants of the São Francisco neighborhood as possible and in obtaining financial resources for actions related to work needs and leisure activities, as well as in sensitizing the representatives of the Municipality of Francisco Beltrão, mediator in the territorial training debated and defined with the inhabitants of the neighborhood. These aspects have generated conflicts and challenges that we try to solve with the dialogues, training courses, planning meetings, and deliberative assemblies already mentioned.

The principles were transformed into guidelines and practices through discussions with the residents of the urban neighborhood. We had debates and together defined the way of working, returning, presenting, and discussing the data collected (aiming at valuing the city subjects, as well as building a more just and democratic society); we (researchers/collaborators and residents) wrote down the analyses characterizing the situation of families and urban plots of land, established the goals, actions, and necessary budget, and elected those responsible for each activity planned and approved in the deliberative assemblies; we discussed and defined the priority actions for the first years of the project, achieving important results such as political formation, regularization of the ownership of urban land and of the housing titling, restoration of collective transport of people, opening of new streets in the neighborhood, installation of public street lighting in the neighborhood, courses on food hygiene and environmental education, creation of a computer lab for neighborhood residents, etc.

Due to the organization and political mobilization built with the residents of the São Francisco neighborhood, the courses of technical and political (in)formation were fundamental for the social achievements, together with the generation of a space for meetings, discussions, and decisionmaking, above all in the community ballroom. They are spaces with the meaning of territories, activation of territorialities, and solidarity, in very locally well-anchored processes, integrating technical and scientific knowledge with norms of public law, especially health, urban infrastructure, and housing. They are urban territories and places for conversation, differences and identities, mobilization, and struggle for a better life, even as a suburban neighborhood: there, in a few years, we could reduce problems and cooperate in the construction of hope. 


\section{Final considerations}

Considering the historical process of the formation of Latin America, in an international movement of colonization, dependence, and environmental degradation, I believe that it is extremely appropriate to assist the economically disadvantaged, slower urban knowledge and rhythms, practices that are very important for preserving nature, recovering degraded environments, valuing popular and community cultures, activating territorialities, and enhancing selforganization. It is essential to support ourselves in urban life and in simpler life and practice values without major private and impactful investments, as we did through the PVB.

It is a possible paradigm of scientific analysis and cooperation in everyday practice to be built with the population by dialoguing, debating, working, resisting, and struggling directly with them. According to us, this is a substantive way of breaking with the colonialism perpetuated by dominant and Eurocentric paradigms (Quijano, 2000; Fals Borda and Mora-Osejo, 2004; Teubal, 2011), without disregarding theoretical, conceptual, and methodological contributions built outside Latin America. This relationship needs to be much more horizontal, respectful, creative, reflective, and dialogic. "We have to foster such interaction with the knowledge of our history, our geographical realities, our resources in such a way that results in shared values, generators of solidarity and strengtheners of our cultural identity" (Fals Borda and Mora-Osejo, 2004:5).

It is necessary, therefore, to dissolve the prison of the unique thought (Esteva, 2011), understood here as one of the mediations for the oppression, control, appropriation, degradation, and domination of the Latin American population, also emanated, institutionalized, and reproduced from and within Latin America by individuals and groups that have been viewed as the only ones who think, create, criticize, and propose, as I have already warned in Saquet (2014). There are dominating relations in the north-south direction; however, there are also dominating relations in the south-south and south-north directions, although the first two, it seems, are largely predominant.

Thus, I identify in the population, the economically disadvantaged, a power or an important human capital that can be mobilized through an endogenous territorial strategy that, in turn, depends directly on political decisions for the construction of a more just and less unequal society (Martínez Valle, 2007) from the place, anchoring, recognition, active territoriality, consciousness of incompleteness, synergy, and class and place consciousness.

We believe, therefore, that our practice of research and cooperative action contains very well-defined and concrete meanings in favor of the integration of popular, technical, and scientific knowledge, solidarity, and political and cultural (in)formation, contributing to making visible the most disadvantaged, valuing them in order for them to build places of decision-making autonomy in a broader social movement that we can call counter-hegemonic. It has this meaning because research and actions were carried out to meet the objectives and part of the needs of the residents of the neighborhood, with their continued participation, conserving nature and valuing the subjects politically and culturally. Working with them on the urban scale has proved fundamental because of the strengthened political identity, the political mobilization, and the struggle built before the dominant political agents. The (in)formation during the project was also central, guiding the realization of popular actions.

Despite the difficulties and constant limitations we experienced during the PVB, we were able to systematically collaborate in the qualification of class and place consciousness, through a practice of cooperation, mobilization, and joint struggle, enhancing the singularities of the territory studied and directly contributing to make feasible, expand, and qualify the popular participation in an urban space of intense inequalities and differences, injustices, and exclusions. Utopia and hope materialized in the solidary, dialogic, and cooperative practice.

Data availability. Data sets are available upon request by contacting the correspondence author.

Competing interests. The authors declares that he has no conflict of interest.

Acknowledgements. I thank the Conselho Nacional de Desenvolvimento Científico $(\mathrm{CNPq})$ for the productivity grant I received. Translation: Oscar Garcia. Final review: Adrialdo de Oliveira. I thank the two referees for their criticism and guidance, which helped greatly improve the paper.

Edited by: Myriam Houssay-Holzschuch

Reviewed by: two anonymous referees

\section{References}

Bagnasco, A.: Problematiche dello sviluppo e articolazione dell'analisi: un paradigma per l'analisi territoriale, in: Le problematiche dello sviluppo italiano, edited by: Bagnasco, A., Messori, M., and Trigilia, C., Feltrinelli, Milão, 205-251, 1978.

Bartolomé, M.: Bases culturais da identidade étnica no México, in: Região e nação na América Latina. Brasília, edited by: Zarur, G., Imprensa Oficial do Estado, São Paulo, 135-161, 2000.

Bartra, A.: Campesinos del tercer milenio: aproximaciones a una quimera, Revista ALASRU, Nueva Época, 10, 17-43, 2014a.

Bartra, A.: Campesindios: ethos, clase, predadores, paradigma. Aproximaciones a una quimera, in: Agriculturas campesinas en Latinoamérica - propuestas y desafios, edited by: Hidalgo, F., Houtart, F., and Lizárraga, P., Editorial IAEN, Quito, 269-276, 2014 b. 
Becattini, G.: Il distretto industriale marshalliano come concetto socio-economico. in: Il distretto industriale, edited by: Becattini, G., Rosenberg \& Sellier, Torino, 57-78, 2000.

Becattini, G.: Ritorno al territorio, Il Mulino, Bologna, 2009.

Becattini, G.: La coscienza dei luoghi. Il territorio come soggetto corale, Donzelli, Roma, 2015.

Becattini, G. and Magnaghi, A.: Coscienza di classe e coscienza di luogo, in: La coscienza dei luoghi, edited by: Becattini, G., Donzelli, Roma, 115-222, 2015.

Brunet, R.: Produzione di territorio: attori e leggi nel mondo reale, in: Le frontiere della Geografia: testi, dialoghi e racconti per Giuseppe Dematteis, UTET, Novara-Torino, 213-226, 2009.

Camagni, R.: Le reti di città in Lombardia: introduzione e sintesi della ricerca, in: Le reti di città. Teoria, politiche e analisi nell'area padana, edited by: Camagni, R. and De Blasio, G., Franco Angeli, Milão, 21-52, 1993.

Camagni, R.: Luoghi e reti nelle politiche di competitività territoriale, in: Strategie di competitività territoriale: il paradigma a rete, edited by: Camagni, R. and Capello, R., SEAT, Torino, 167-179, 1997.

Coraggio, J. L.: Desarrollo local y municipios participativos, in: Descentralizar: barajar y dar de nuevo. La participación en juego, edited by: Coraggio, J. L., FLACSO Equador, Quito, 159-172, 2004.

Dansero, E. and Zobel, B.: Verso un dialogo tra comunità scientifica e comunità locale, in: Promozione della sostenibilità nel Pinerolese - un percorso di ricerca/azione territoriale, Euro Mountains, Turim, 135-141, 2007.

Dematteis, G.: Le metafore della terra. La geografia umana tra mito e scienza, Feltrinelli, Milano, 1985.

Dematteis, G.: Progetto implicito. Il contributo della geografia umana alle scienze del territorio, Angeli, Milano, 1995.

Dematteis, G.: Per una geografia della territorialità attiva e dei valori territoriali, in: Slot, quaderno 1, edited by: Bonora, P., Baskerville, Bologna, 11-30, 2001.

ECLAC - CEPAL - Comissão Econômica para a América Latina e Caribe, CEPALSTAT - Publicações Estatísticas: Disponíveis em: http://estadisticas.cepal.org/cepalstat/WEB_CEPALSTAT/ perfilesNacionales.asp?idioma $=\mathrm{e}$ (last access: 20-22 September 2016), 2013-2015.

Esteva, G.: Regreso del future, in: Bicentenarios (otros), transiciones y resistencias, edited by: Giarracca, N., Una Ventana, Buenos Aires, 47-58, 2011.

Fals Borda, O.: La ciencia y el pueblo, in: Investigación participativa y praxis rural, edited by: Grossi, F., Gianotten, V., and Wit, T., Mosca Azul, Lima, 19-47, 1981.

Fals Borda, O.: Democracia y participación: algunas reflexiones, Revista Colombiana de Sociología, 5, 35-40, 1987.

Fals Borda, O.: Orígenes universales y retos actuales de la IAP (Invetigación Acción Participativa), Peripecias, 110, 1-14, 2008.

Fals Borda, O. and Mora-Osejo, L. E.: La superación del eurocentrismo - enriquecimiento del saber sistémico y endógeno sobre nuestro contexto tropical, POLIS - Revista Latinoamericana, 7, $1-6,2004$.

Fals Borda, O. and Mora-Osejo, L. E.: La superación del eurocentrismo - manifiesto por la ciencia, in: Orlando Fals Borda - Socialismo raizal y el ordenamiento territorial, Desde Abajo, Bogotá, 219-230, 2013.

Freire, P.: Pedagogia do oprimido, Paz e Terra, São Paulo, 2011a.
Freire, P.: Pedagogia da autonomia, Saberes necessários à prática educativa, Paz e Terra, São Paulo, 2011b.

Garavito, C. R.: Etnicidad.gov - Los recursos naturales, los pueblos indígenas y el derecho a la consulta previa en los campos sociales minados, Centro de Estudios de Derecho, Justicia y Sociedad, Dejusticia, Bogotá, 2012.

Harguindeguy, L. C.: Economía solidaria: local y diversa, El Colegio de Tlaxcala, Talxcala, México, 2014.

Harvey, D.: O trabalho, o capital e o conflito de classes em torno do ambiente construído nas sociedades capitalistas avançadas, Espaço e Debates, São Paulo, 6-35, 1982.

Hidalgo, F.: Contextos y tendencias de las agriculturas en Latinoamérica actual, in: Agriculturas campesinas en Latinoamérica - propuestas y desafios, edited by: Hidalgo, F., Houtart, F., and Lizárraga, P., Editorial IAEN, Quito, 67-86, 2014.

Hidalgo, F. and Fernández, Á.: Contrahegemonia y buen vivir, Universidad Central del Ecuador y Universidad del Zulia (Venezuela), Quito, 2012.

Indovina, F. and Calabi, D.: Sull'uso capitalistico del territorio, in: Economia e territorio, edited by: Lusso, G., Angeli, Milano, 205222, 1974.

Lizárraga, P. and Vacaflores, C.: Lo agrario en la reconstitución del sujeto indígena originario campesino, in: Agriculturas campesinas en Latinoamérica - propuestas y desafios, edited by: Hidalgo, F., Houtart, F., and Lizárraga, P., Editorial IAEN, Quito, 277-296, 2014.

Llambí, L.: Procesos de transformación de los territórios rurales latinoamericanos: los retos de la interdisciplinariedad, Eutopía, 3, 117-134, 2012.

Magnaghi, A.: Il territorio nella crisi, Quaderni del territorio, CELUC Libri, Milano, 15-29, 1976.

Magnaghi, A.: Il progetto locale, Bollati Boringhieri, Torino, 2000.

Magnaghi, A.: Dalla partecipazione all'autogoverno della comunità locale: verso il federalismo municipale solidade, Democrazia e Diritto, 3, 1-13, 2006.

Magnaghi, A.: La lunga marcia del ritorno al territorio, in: La coscienza dei luoghi, edited by: Becattini, G., Donzelli, Roma, VIIXVI, 2015.

Martínez Valle, L.: Puede la pobreza rural ser abordada a partir de lo local?, Íconos, 29, 51-61, 2007.

Martínez Valle, L.: Asalariados rurales en territorios del agronegocio: flores y brócoli em Cotopaxi, FLACSO Ecuador, Quito, 2015.

Mignolo, W.: Historias locales/diseños globales, Ed. Akal, Madrid, 2003.

Padilla, M. C. and Guzmán, E. S.: Aportando a la construcción de la soberanía alimentaria desde la agroecología, Ecología política, 38, 43-51, 2009.

Pecqueur, B. and Zimmermann, J.: Les fondementsd'une économie de proximités, DT 02A26, GREQAM, Marseille, 1-23, 2002.

Quaini, M.: Dalla coscienza di classe alla "coscienza di luogo" ovvero "de la lutte des classes à la lutte des places". Declinazioni del concetto di luogo e di paesaggio, Fondazione Benetton, Treviso, 1-13, 2010.

Quijano, A.: Reencuentro y debate: una introducción a Mariátegui, Mosca Azul, Lima, 1981.

Quijano, A.: El fantasma del desarrollo en América Latina, Rev. Venezolana de Economía y Ciencias Sociales, 6, 73-90, 2000. 
Quijano, A.: O que é essa tal de raça?, in: Diversidade, espaço e relações étnico-raciais, edited by: Santos, R., Ed. Gutenberg, Belo Horizonte, 43-51, 2007.

Racine, J.-B.: La territorialité, référentiel obligé de la géographie? Une théorie encore à construire, in: La territorialite: une theorie a construire - en hommage à Claude Raffestin, edited by: Racine, J.-B., Hussy, J., Bacony, P., Hussy, C., Moeschler, P., and Tschopp, P., Departement de Géographie - Université de Genéve, Genebra, 5-16, 2002.

Raffestin, C.: Paysage et territorialitè, Cahiers de géographie du Québec, 53-54, 123-134, 1977.

Raffestin, C.: Por uma geografia do Poder, Ática, São Paulo, 1993.

Raffestin, C.: Territorializzazione, deterritorializzazione, riterritorializzazione e informazione, in: Regione e regionalizzazione, edited by: Turco, A., Franco Angeli, Milano, 69-82, 1984.

Raffestin, C.: Punti di riferimento per una teoria della territorialità umana, in: Esistere ed abitare. Prospettive umanistiche nella geografia francofona, edited by: Copeta, C., Franco Angeli, Milano, 75-89, 1986.

Raffestin, C.: Reperès pour une théorie de la territorialitè humaine, Cahier/Groupe reseaux, 7, 2-22, 1987.

Raffestin, C.: Immagini e identità territoriali, in: Il mondo e i luoghi: geografie delle identità e del cambiamento, edited by: Dematteis, G. and Ferlaino, F., IRES, Torino, 3-11, 2003.

Raffestin, C.: Dalla nostalgia del territorio al desiderio di paesaggio. Elementi per una teoria del paesaggio, Alinea, Firenze, 2005.

Rodríguez, V., Lizárraga, P., and Bórquez, L.: Procesos políticos y movimientos campesinos e indígenas en Abya Yala, in: Agriculturas campesinas en Latinoamérica - propuestas y desafios, edited by: Hidalgo, F., Houtart, F., and Lizárraga, P., Editorial IAEN, Quito, 167-177, 2014.

Rullani, E.: Più locale e più globale: verso una economia postfordista del territorio, in: La dinamica dei sistemi produttivi territoriali: teorie, tecniche, politiche, edited by: Bramanti, A. and Maggioni, M., Franco Angeli, Milano, 85-111, 1997.

Rullani, E., Micelli, S., and Di Maria, E. (Eds.): Tra città reale e città virtuale: il territorio nel postfordismo, in: Città e cultura nell'economia delle reti, Mulino, Bologna, 13-56, 2000.
Sánchez, A.: Dilemas teóricos y metodológicos de la sociología rural en América Latina, Revista ALASRU - Nueva Época, 10, 359-380, 2014.

Saquet, M.: Os tempos e os territórios da colonização italiana, EST Edições, Porto Alegre/RS, 2003.

Saquet, M.: Abordagens e concepções de território, Expressão Popular, São Paulo, 2007.

Saquet, M.: Por uma abordagem territorial, in: Territórios e territorialidades: teorias, processos e conflitos, edited by: Saquet, M. and Sposito, E., Expressão Popular, São Paulo, 73-94, 2009.

Saquet, M.: Il territorio della geografia, Franco Angeli, Milão, 2012.

Saquet, M.: L'approche territoriale historico-critique et relationnelle: une analyse comparative, Les Cahiers du Developpement Durable, 16, 229-247, 2014.

Saquet, M.: Por uma Geografia das territorialidades e das temporalidades: uma concepção multidimensional voltada para a cooperação e para o desenvolvimento territorial, Editora Consequência, Rio de Janeiro, 2015.

Saquet, M.: Territory, geographical indication and territorial development, Desenvolvimento Regional em debate, 6, 4-21, 2016.

Saquet, M.: Consciência de classe e de lugar, práxis e desenvolvimento territorial, Consequência, Rio de Janeiro, 2017.

Saquet, M. and Flávio, L. C.: Contribuições para o planejamento e a gestão urbana: a experiência do Projeto Vida no Bairro - Francisco Beltrão (PR), GUAJU - Revista Brasileira de Desenvolvimento Territorial, 1, 123-141, 2015.

Saquet, M., Pacífico, J., and Flávio, L. C.: Cidade, organização popular e desenvolvimento: a experiência do Projeto Vida no Bairro, UNIOESTE, Cascavel/PR, 2005.

Schwarz, A. and Streule, M.: A transposition of territory: decolonized perspectives in current urban research, Int. J. Urban Reg. Res., 5, 1000-1016, 2017.

Teubal, M.: Apuntes sobre el desarrollo, in: Bicentenarios (otros), transiciones y resistencias, edited by: Giarracca, N., Una Ventana, Buenos Aires, 185-207, 2011.

Vazquez, A.: Filosofia da Praxis, Paz e Terra, Rio de Janeiro, 1990.

Zibechi, R.: Territórios em resistência, Consequência, Rio de Janeiro, 2015. 